\title{
Symptomatic hyponatraemia: can myelinolysis be prevented by treatment?
}

\author{
Cheryl P Harris, Jeannette J Townsend, J Richard Baringer
}

\begin{abstract}
The treatment of hyponatraemia is controversial because of the risk of causing central or extrapontine myelinolysis (EPM). Rapid correction with hypertonic saline to a low normal sodium level has its proponents; others feel that slow correction to below normal sodium values is preventative. Most investigators feel that overcorrection should be avoided. It is not known whether the magnitude of serum sodium change is more important than the actual rate of correction. We present three patients with hyponatraemia ranging from 103 to $105 \mathrm{mmol} / \mathrm{l}$ who were corrected slowly with normal saline, corrected quickly with hypertonic saline, or rapidly overcorrected with hypertonic saline. All became comatose and died; all had EPM with or without central pontine myelinolysis (CPM). The rate of correction, the solution used, or the magnitude of correction did not seem to protect against demyelination. In a review of 67 reported CPM cases since 1983, no patients documented as having CPM or EPM by radiological studies or necropsy were treated with water restriction only. A group of 27 hyponatraemic patients treated only with water restriction and 35 with diuretic cessation alone did not develop CPM or EPM. This may be a reasonable approach to patients with symptomatic hyponatraemia and normal renal function.
\end{abstract}

(F Neurol Neurosurg Psychiatry 1993;56:626-632)

Controversy continues concerning the treatment of patients with hyponatraemia. Some proponents argue that fast correction with hypertonic saline to below normal values is indicated, ${ }^{12}$ while others state that slow correction to below normal values will prevent neurological sequelae. ${ }^{34}$ Most clinicians feel that overcorrection should be avoided. ${ }^{12} \mathrm{We}$ describe three patients who presented with hyponatraemia. One was treated with slow correction, one with fast correction, and a third was overcorrected. All developed neurological symptoms leading to coma and death. All three demonstrated neuropathological changes of demyelination, either in the form of central or extrapontine myelinolysis. We review the various recommendations for treating hyponatraemia and summarise various possible pathogenetic mechanisms.

\section{Case histories}

PATIENT 1

A 44 year old previously healthy woman developed a gastrointestinal viral illness two weeks before admission. Nausea, vomiting, and diarrhoea prompted an increase in water intake during this period. She became comatose at home and was admitted to hospital. On examination her temperature was $38 \cdot 3^{\circ} \mathrm{C}$. She was described as restless but responsive to deep pain. No focal neurological abnormalities were documented. Laboratory studies revealed a serum sodium of $103 \mathrm{mmol} / \mathrm{l}$, chloride of $70 \mathrm{mmol} / \mathrm{l}$, potassium of $2.7 \mathrm{mmol} / \mathrm{l}$, haematocrit of 48 and a white blood cell count of $20 \times 10^{9} / 1$ with $85 \%$ polymorphonuclear leucocytes. A chest $x$ ray demonstrated possible basilar infiltrates. Lumbar puncture and CT scan of the head were normal. The patient was treated with fluid restriction and infusion of normal saline at approximately $0.37 \mathrm{mmol}$ per hour. Over the next several days her sensorium steadily improved and the serum sodium was 130 mmol/1 by the third hospital day. Two days later, however, she developed dysphagia, dysarthria, and a diminished state of responsiveness. By the seventh hospital day she had become increasingly apathetic and mute. Multiple cultures of urine, blood, throat, and stool were negative. A CT scan, brainstem evoked responses, and an EEG were normal.

During the next two weeks, the woman remained mute with limited spontaneous movement of the extremities and a slight increase in flexor tone. The pupillary responses were normal. Deep tendon reflexes were hyperactive and the plantar responses were extensor bilaterally. No source of infection was located despite persistent rectal temperatures of $108^{\circ} \mathrm{F}$. No seizures were observed. The patient died 15 days after admission.

No infectious source was discovered at necropsy. Incidental findings included a small adenocarcinoma of the thyroid and a pituitary adenoma. The brain weighed 1150 grams and demonstrated mild cortical atrophy of the frontoparietal regions bilaterally. Coronal sections revealed ex-vacuo dilatation of the lateral and third ventricles. The cortical ribbon was thinned and the sulci were slightly widened. The basal ganglia, cerebellum, and brainstem were normal in gross appearance. Microscopic examination of the cortex revealed neuronal loss with astrocytosis, macrophage infiltration, and neovascularisation primarily confined to the third neuronal 
layer. The hippocampus and cerebellum had normal neuronal populations. Bilateral severe demyelination of the white matter tracts in the putamen and caudate nuclei was seen with a brisk macrophage response. The putamen was diffusely gliotic and there was a mild loss of small neurons with a relative preservation of the larger neurons. A rostral section of the pons did not reveal demyelination, and sections of the globus pallidus, thalamus, hypothalamus, and mamillary bodies were normal.

\section{PATIENT 2}

A 68 year old woman with a long history of hypertension, rheumatoid arthritis, and chronic neck pain entered hospital for a cervical myelogram. She had been treated with reserpine, a thiazide diuretic, and low dose prednisone for several years. Her husband stated that an upper respiratory illness over the previous two weeks had caused the patient to increase her water intake. Admission laboratory studies revealed a serum sodium level of $121 \mathrm{mmol} / \mathrm{l}$ and potassium of $2.6 \mathrm{mmol} / \mathrm{l}$. The cervical myelogram demonstrated subluxation of the odontoid process and compromise of the anteroposterior diameter at $\mathrm{C} 1-\mathrm{C} 2$. On the day after the myelogram, the patient vomited and was hydrated with D5 $1 / 4 \mathrm{NS}$ at $100 \mathrm{ml} /$ hour. She was confused and mentally slowed, worsening as the day progressed. On examination, she was disoriented to time and place but was not dysphasic and could move all four extremities normally. Later that day, however, she became comatose with minimal response to painful stimulation. Pupils were midposition but miotic, though they reacted directly and consensually to light. Oculocephalic manoeuvers were normal. No posturing was noted, but bilateral Babinski signs were present.

Because the inital lumbar puncture for the myelogram demonstrated $323 \times 10^{6} / 1$ red blood cells, it was felt that the patient may have suffered a subarachnoid haemorrhage. She was treated with steroids and frusemide. Laboratory studies revealed a sodium level of $104 \mathrm{mmol} / \mathrm{l}$, potassium $2 \cdot 2 \mathrm{mmol} / \mathrm{l}$, chloride $73 \mathrm{mmol} / \mathrm{l}$, and carbon dioxide $21 \mathrm{mmol} / 1$. Treatment for the hyponatraemia was begun with $5 \%$ sodium chloride at a rate of 2.9 $\mathrm{mmol} /$ hour with added potassium replacement; the steroids were continued. Within eight hours, the patient's sodium had risen to $127 \mathrm{mmol} / \mathrm{l}$, and the potassium to $3 \mathrm{mmol} / 1$. Clinically, she was more alert but dysarthric, and weakness was noted in the left arm. Sodium replacement was changed to a normal saline infusion, and in 24 hours the serum sodium was $130 \mathrm{mmol} / \mathrm{l}$. By the next morning, however, the patient was obtunded and would not follow commands, though she moved all four extremities spontaneously. CT scan was normal, and an EEG demonstrated bilateral synchronous periodic sharp waves. The patient required treatment with intravenous nitroprusside for an acute elevation of blood pressure. Over the course of the follow- ing week, she became comatose and remained unchanged. Serum sodium levels were maintained between 128 and 130 $\mathrm{mmol} / \mathrm{l}$. The patient died in a nursing home six weeks later.

Necropsy revealed pneumonia and diffuse atherosclerosis. The brain weighed 1100 grams and was not oedematous. There were mild atherosclerotic changes in the circle of Willis. Coronal sections demonstrated thinning of the cortex with a dark line in the lower layers at the grey-white junction, most prominent in the frontoparietal areas. The hippocampus was also thinned and discoloured. The basal ganglia, cerebellum, and brainstem were grossly unremarkable. Microscopically, the cortex revealed neuronal loss with astrocytosis, macrophage proliferation, and neovascularisation in the lower layers of the cortical ribbon. The hippocampus also contained a focal area of neuronal loss in the pyramidal cell layer. White matter tracts in the caudate and putamen demonstrated striking demyelination bilaterally with the presence of macrophages. Two rostral sections of the pons did not reveal any demyelination, and a mild dropout of Purkinje cells was noted in the cerebellar cortex.

\section{PATIENT 3}

A 55 year old woman developed an upper respiratory illness ten days before admission. Treatment with erythromycin did not improve her symptoms. She developed general malaise, myalgias, nausea, and dizziness and was admitted to hospital. She appeared pale and confused, and was unable to recall appropriate details of her medical history. Neurological examination demonstrated only unsteadiness of gait. While waiting for a chest $x$ ray, the patient became unresponsive for a few seconds; a clinical suspicion of a seizure was entertained. Laboratory examination revealed a serum sodium of $106 \mathrm{mmol} / \mathrm{l}$, potassium $2.6 \mathrm{mmol} / \mathrm{l}$, with serum osmolarity 219 mOsm, and urine $330 \mathrm{mOsm}$. Haematocrit was 31.9 and the white blood cell count was $14.3 \times 10^{9} / 1$ with $89 \%$ neutrophils and $11 \%$ bands. Chest $x$ ray demonstrated mild bilateral infiltrates and CT scan of the brain was normal.

The patient was treated with fluid restriction and phenytoin. After 12 hours, the serum sodium remained at $106 \mathrm{mmol} / \mathrm{l}$, and she was given $5 \%$ sodium chloride at 1.7 $\mathrm{mmol} /$ hour, and frusemide. After nearly nine hours of this therapy, the sodium was 109 $\mathrm{mmol} / \mathrm{l}$. Infusion of $5 \%$ sodium chloride was continued, and after an additional nine hours, her serum sodium was $150 \mathrm{mmol} / 1$. The patient's sensorium remained clouded and the following day she became more lethargic and tachypnoeic. Arterial blood gases demonstrated hypoxia and she was intubated and placed on a ventilator. During this time she became progressively more obtunded, and by the morning of the fourth hospital day, she was unresponsive to verbal stimuli. Neurological examination revealed flaccid tetraparesis with minimal reaction to painful 
stimuli. Spontaneous respirations were present. Funduscopic examination demonstrated sharp discs and no retinal haemorrhages. Pupillary examination was unremarkable and doll's eyes and corneal reflexes were normal. No spontaneous movement of the extremities was seen and the plantar responses were extensor bilaterally. Serum sodium on the fourth hospital day was $152 \mathrm{mmol} / 1$ and potassium was $3 \mathrm{mmol} / 1$. A lumbar puncture revealed $456 \times 10^{6} / 1$ red blood cells, $7 \times 10^{6} / 1$ blood cells; protein was $39 \mathrm{mg} / \mathrm{dl}$ and glucose $99 \mathrm{mg} / \mathrm{dl}$. Cultures of the spinal fluid were sterile and a repeat CT scan of the brain was normal. Haematological studies demonstrated persistent anaemia and thrombocytopenia. EEG showed diffuse slowing of the background with features consistent with a diffuse encephalopathy. The patient remained comatose until her death on the thirteenth hospital day.

A limited necropsy revealed bronchopneumonia and acute haemorrhagic necrosis of both adrenal glands. Sections of the brain were limited to the diencephalon and brainstem. The thalamus, internal capsule, and basal ganglia demonstrated severe acute demyelination of the white matter tracts and petechial haemorrhages in the thalamus and substantia nigra (fig 1). Microscopically, these areas showed diffuse severe myelinolysis with neuronal cell death. The pons demonstrated numerous areas of acute demyelination (fig 2).

\section{Review of reported central and extrapontine myelinolysis cases}

Sixty seven cases of CPM and EPM have been reported since 1983, when the association of myelinolysis and hyponatraemia was first recognised (table 1). In 38 of these, there was enough information to determine the manner of correction: 21 patients were treated with hypertonic saline and 17 with isotonic saline. Fifty seven reports included

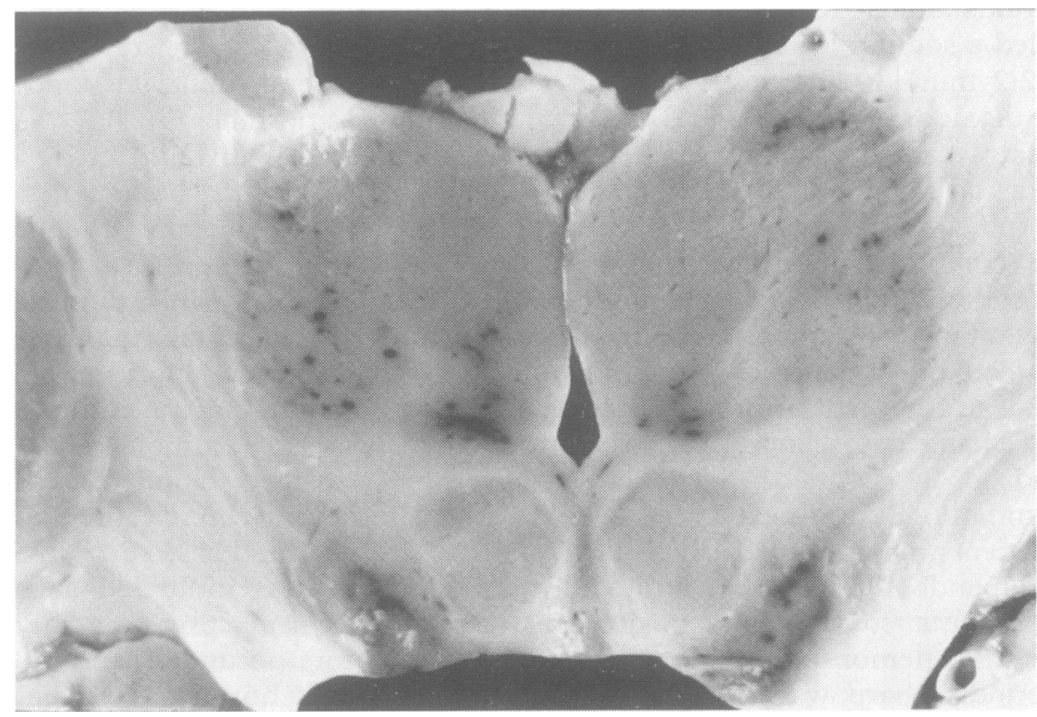

Figure 1 A coronal section through the third ventricle demonstrates acute petechial haemorrhages with histological confirmation of demyelination in the thalamus and midbrain.

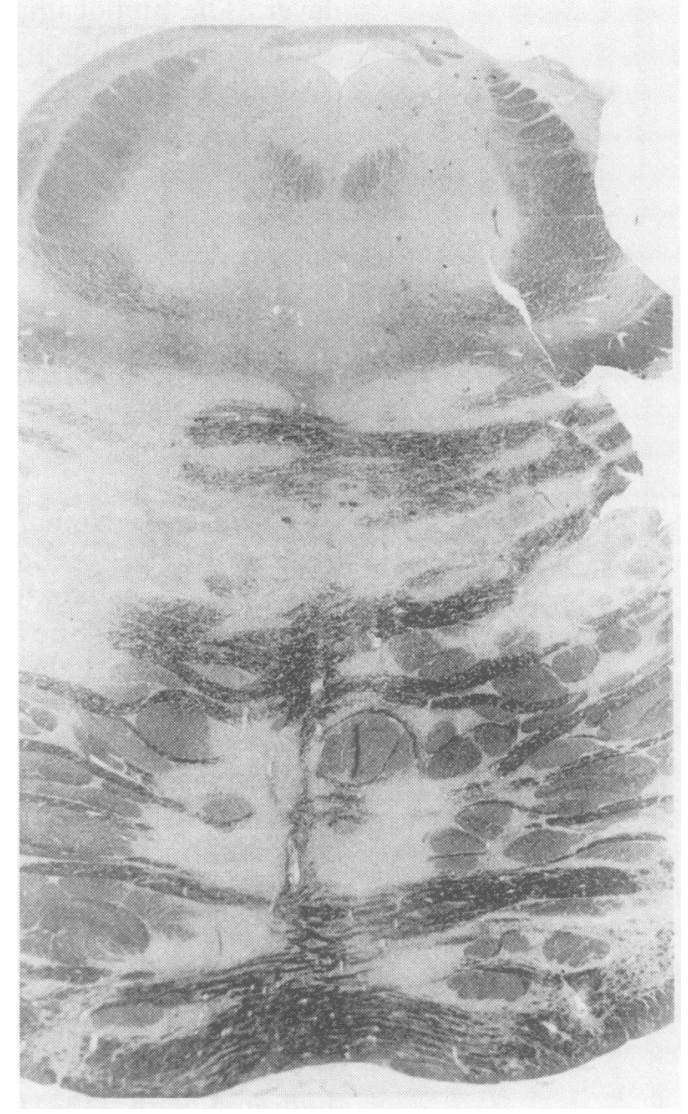

Figure 2 A section from the rostral pons reveals numerous patchy areas of demyelination centrally and laterally (uxol fast blue stain, 7).

information regarding the rate of correction: serum sodium was normalised in 26 patients within 24 hours, and in 31 others was corrected over 30 hours to five days. Of note, serum sodium in 16 of these 31 patients was overcorrected to hypernatraemic levels.

\section{Discussion}

HISTORY AND EPIDEMIOLOGY OF CENTRAL AND EXTRAPONTINE MYELINOLYSIS

Central pontine myelinolysis (CPM) was originally documented by Adams et al in patients suffering from alcoholism or malnourishment. ${ }^{36}$ Although many of the patients reported subsequently with myelinolysis were also alcoholics, CPM is known to occur in hyponatraemic non-alcoholic patients. These groups comprise patients who have been treated with diuretics, ${ }^{37-40}$ overhydrated postoperatively, ${ }^{41}$ become dehydrated because of vomiting or diarrhoea, ${ }^{313942}$ or have been compulsive water drinkers. ${ }^{6}$ Subsequently it has been recognised that electrolyte imbalances $^{43}$, especially hyponatraemia, ${ }^{44}$ are common antecedents of CPM. A great deal of controversy in recent years has revolved around the underlying mechanism causing the lesions. Most investigators feel that the cause is iatrogenic and secondary to changes in the serum sodium levels. ${ }^{34-48}$ In recent years, the majority of patients with this syndrome have had documented hyponatraemia and have had their serum sodium levels 
Table 1 Reported CPM cases since 1983

\begin{tabular}{|c|c|c|c|c|c|c|c|}
\hline $\begin{array}{l}\text { Reference } \\
\text { No }\end{array}$ & Age/gender & $\begin{array}{l}\text { Predisposing } \\
\text { condition }\end{array}$ & $\mathrm{Na}^{+}$, initial & Treatment & $\mathrm{Na}^{+}$, after $\mathrm{Rx}$ & Time interval & Pathology* \\
\hline $\begin{array}{r}5 \\
6 \\
6 \\
7 \\
8 \\
9 \\
10 \\
10 \\
3 \\
3 \\
3 \\
3 \\
3 \\
3 \\
3 \\
3 \\
11 \\
2 \\
2 \\
2 \\
2 \\
2 \\
2 \\
2 \\
2 \\
2 \\
2 \\
2 \\
2 \\
12 \\
13 \\
14 \\
15 \\
15 \\
15 \\
15 \\
15 \\
15 \\
15 \\
15 \\
15 \\
15 \\
15 \\
16 \\
17 \\
18 \\
19 \\
20 \\
21 \\
22 \\
23 \\
24 \\
25 \\
26 \\
27 \\
27 \\
27 \\
28 \\
29 \\
30 \\
31 \\
32 \\
33 \\
34 \\
35 \\
35 \\
35\end{array}$ & $\begin{array}{l}51, \mathrm{f} \\
40, \mathrm{~m} \\
48, \mathrm{~m} \\
34, \mathrm{~m} \\
52, \mathrm{f} \\
50, \mathrm{~m} \\
46, \mathrm{~m} \\
39, \mathrm{~m} \\
54, \mathrm{f} \\
54, \mathrm{f} \\
60, \mathrm{~m} \\
68, \mathrm{f} \\
74, \mathrm{f} \\
75, \mathrm{f} \\
77, \mathrm{f} \\
41, \mathrm{~m} \\
61, \mathrm{f} \\
59, \mathrm{~m} \\
56, \mathrm{~m} \\
39, \mathrm{~m} \\
56, \mathrm{~m} \\
53, \mathrm{f} \\
69, \mathrm{f} \\
16, \mathrm{~m} \\
54, \mathrm{f} \\
49, \mathrm{f} \\
47, \mathrm{f} \\
77, \mathrm{f} \\
43, \mathrm{~m} \\
54, \mathrm{~m} \\
41, \mathrm{~m} \\
74, \mathrm{~m} \\
54, \mathrm{f} \\
21, \mathrm{~m} \\
28, \mathrm{f} \\
23, \mathrm{f} \\
23, \mathrm{~m} \\
43, \mathrm{~m} \\
33, \mathrm{~m} \\
45, \mathrm{~m} \\
18, \mathrm{~m} \\
4, \mathrm{f} \\
8, \mathrm{f} \\
53, \mathrm{~m} \\
20, \mathrm{f} \\
59, \mathrm{f} \\
56, \mathrm{f} \\
17, \mathrm{f} \\
28, \mathrm{~m} \\
53, \mathrm{~m} \\
50, \mathrm{f} \\
37, \mathrm{f} \\
58, \mathrm{f} \\
6, \mathrm{f} \\
18, \mathrm{f} \\
82, \mathrm{f} \\
52, \mathrm{f} \\
61, \mathrm{f} \\
65, \mathrm{~m} \\
\mathrm{NA,m} \\
29, \mathrm{f} \\
46, \mathrm{~m} \\
40, \mathrm{~m} \\
55, \mathrm{~m} \\
66, \mathrm{~m} \\
54, \mathrm{~m} \\
68, \mathrm{f}\end{array}$ & $\begin{array}{l}\text { alcoholic } \\
\mathrm{H}_{2} \mathrm{O} \text { drinker } \\
\mathrm{H}_{2} \mathrm{O} \text { drinker } \\
\text { alcoholic } \\
\text { overhydration } \\
\text { alcoholic } \\
\text { alcoholic } \\
\text { alcoholic } \\
\mathrm{NA} \\
\text { diuretics } \\
\text { diuretics } \\
\text { diuretics } \\
\text { diuretics } \\
\text { diuretics } \\
\text { alcoholic } \\
\text { alcoholic } \\
\text { vomiting } \\
\mathrm{NA} \\
\mathrm{NA} \\
\mathrm{NA} \\
\mathrm{NA} \\
\mathrm{NA} \\
\text { diuretics } \\
\mathrm{NA} \\
\text { diuretics } \\
\text { diuretics } \\
\text { alcoholic } \\
\text { overhydration } \\
\text { overhydration } \\
\text { alcoholic } \\
\text { alcoholic } \\
\text { bladder flush } \\
\text { liver } \mathrm{tx} \\
\text { liver } \mathrm{tx} \\
\text { liver } \mathrm{tx} \\
\text { liver tx } \\
\text { liver tx } \\
\text { liver tx } \\
\text { liver tx } \\
\text { liver tx } \\
\text { liver tx } \\
\text { liver tx } \\
\text { liver tx } \\
\text { alcoholic } \\
\text { vomiting } \\
\text { diuretics } \\
\text { diuretics } \\
\mathrm{NA} \\
\text { alcoholic } \\
\text { alcoholic } \\
\text { alcoholic } \\
\text { alcoholic } \\
\text { IV fluids } \\
\mathrm{NA} \\
\text { vomiting } \\
\text { diuretics } \\
\text { diuretics } \\
\text { alcoholic } \\
\text { alcoholic } \\
\text { alcoholic } \\
\text { diarrhea } \\
\text { alcoholic } \\
\mathrm{NA} \\
\text { alcoholic } \\
\text { DI, lymphoma } \\
\text { alcoholic } \\
\text { esophageal CA }\end{array}$ & $\begin{array}{l}94 \mathrm{meq} / 1 \\
93 \mathrm{mmol} / \\
96 \mathrm{mmol} / 1 \\
111 \mathrm{meq} / 1 \\
97 \mathrm{meq} / 1 \\
102 \mathrm{meq} / 1 \\
100 \mathrm{meq} / 1 \\
107 \mathrm{meq} / 1 \\
102 \mathrm{mmol} / 1 \\
109 \mathrm{mmol} / 1 \\
105 \mathrm{mmol} / 1 \\
103 \mathrm{mmol} / 1 \\
115 \mathrm{mmol} / 1 \\
114 \mathrm{mmol} / 1 \\
98 \mathrm{mmol} / \\
109 \mathrm{mmol} / 1 \\
95 \mathrm{mmol} / 1 \\
149 \mathrm{mmol} / 1 \\
129 \mathrm{mmol} / 1 \\
134 \mathrm{mmol} / 1 \\
130 \mathrm{mmol} / 1 \\
102 \mathrm{mmol} / 1 \\
100 \mathrm{mmol} / 1 \\
99 \mathrm{mmol} / \\
91 \mathrm{mmol} / \\
91 \mathrm{mmol} / \\
96 \mathrm{mmol} / 1 \\
98 \mathrm{mmol} / \\
103 \mathrm{mmol} / 1 \\
104 \mathrm{meq} / 1 \\
93 \mathrm{mmol} / 1 \\
116 \mathrm{mmol} / 1 \\
129 \mathrm{meq} / 1 \\
121 \mathrm{meq} / 1 \\
120 \mathrm{meq} / 1 \\
130 \mathrm{meq} / 1 \\
122 \mathrm{meq} / 1 \\
126 \mathrm{meq} / 1 \\
118 \mathrm{meq} / 1 \\
121 \mathrm{meq} / 1 \\
131 \mathrm{meq} / 1 \\
126 \mathrm{meq} / 1 \\
\mathrm{NA} \\
104 \mathrm{meq} / 1 \\
103 \mathrm{meq} / 1 \\
105 \mathrm{mmol} / 1 \\
113 \mathrm{mmol} / 1 \\
100 \mathrm{meq} / 1 \\
126 \mathrm{meq} / 1 \\
104 \mathrm{meq} / 1 \\
108 \mathrm{meq} / 1 \\
112 \mathrm{meq} / 1 \\
110 \mathrm{meq} / 1 \\
\mathrm{NA} \\
126 \mathrm{meq} / 1 \\
124 \mathrm{meq} / 1 \\
99 \mathrm{mmo} / / \\
120 \mathrm{mmol} / 1 \\
93 \mathrm{meq} / 1 \\
100 \mathrm{mmol} / 1 \\
114 \mathrm{meq} / 1 \\
104 \mathrm{meq} / 1 \\
97 \mathrm{mmo} / / \\
110 \mathrm{mmol} / 1 \\
103 \mathrm{meq} / 1 \\
\mathrm{NA} \\
\mathrm{NA}\end{array}$ & 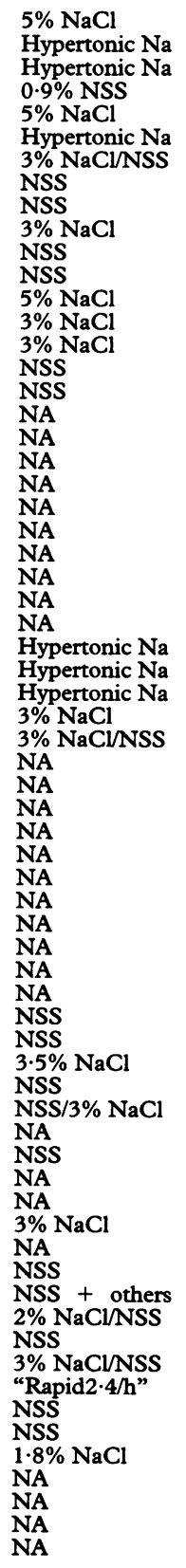 & 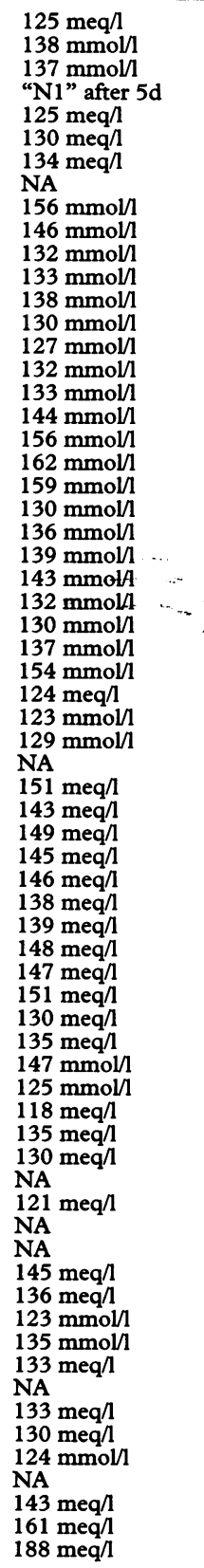 & $\begin{array}{l}24 \text { hours } \\
30 \text { hours } \\
20 \text { hours } \\
5 \text { days } \\
24 \text { hours } \\
24 \text { hours } \\
24 \text { hours } \\
\text { NA } \\
72 \text { hours } \\
72 \text { hours } \\
\text { NA } \\
29 \text { hours } \\
24 \text { hours } \\
21 \text { hours } \\
96 \text { hours } \\
72 \text { hours } \\
5 \text { days } \\
24 \text { hours } \\
48 \text { hours } \\
48 \text { hours } \\
61 \text { hours } \\
15 \text { hours } \\
53 \text { hours } \\
48 \text { hours } \\
34 \text { hours } \\
30 \text { hours } \\
45 \text { hours } \\
37 \text { hours } \\
45 \text { hours } \\
48 \text { hours } \\
24 \text { hours } \\
24 \text { hours } \\
\text { NA } \\
\text { NA } \\
4 \text { days } \\
\text { NA } \\
24 \text { hours } \\
24 \text { hours } \\
3 \text { days } \\
48 \text { hours } \\
3 \text { days } \\
24 \text { hours } \\
\text { NA } \\
24 \text { hours } \\
15 \text { hours } \\
24 \text { hours } \\
6 \text { hours } \\
17 \text { hours } \\
24 \text { hours } \\
24 \text { hours } \\
\text { NA } \\
24 \text { hours } \\
48 \text { hours } \\
\text { NA } \\
48 \text { hours } \\
24 \text { hours } \\
3 \text { days } \\
4 \text { days } \\
24 \text { hours } \\
48 \text { hours } \\
17 \text { hours } \\
48 \text { hours } \\
24 \text { hours } \\
5 \text { days } \\
\text { "Few days" } \\
\text { NA } \\
\text { NA }\end{array}$ & $\begin{array}{l}\text { CPM/EPM } \\
\text { CPM/EPM } \\
\text { CPM/EPM } \\
\text { NA } \\
\text { NA } \\
\text { CPM } \\
\text { NA } \\
\text { NA } \\
\text { CPM/EPM } \\
\text { NA } \\
\text { NA } \\
\text { NA } \\
\text { NA } \\
\text { NA } \\
\text { CPM } \\
\text { NA } \\
\text { NA } \\
\text { Demyelination } \\
\text { Demyelination } \\
\text { Demyelination } \\
\text { Demyelination } \\
\text { Demyelination } \\
\text { Demyelination } \\
\text { Demyelination } \\
\text { Demyelination } \\
\text { Demyelination } \\
\text { Demyelination } \\
\text { Demyelination } \\
\text { Demyelination } \\
\text { CPM/EPM } \\
\text { CPM } \\
\text { NA } \\
\text { CPM/EPM } \\
\text { CPM } \\
\text { CPM } \\
\text { CPM } \\
\text { CPM } \\
\text { CPM/EPM } \\
\text { CPM/EPM } \\
\text { CPM/EPM } \\
\text { CPM } \\
\text { CPM } \\
\text { CPM } \\
\text { CPM } \\
\text { CPM/EPM } \\
\text { CPM/EPM } \\
\text { CPM } \\
\text { NA } \\
\text { NA } \\
\text { NA } \\
\text { CPM } \\
\text { CPM } \\
\text { CPM/EPM } \\
\text { CPM } \\
\text { NA } \\
\text { NA } \\
\text { NA } \\
\text { CPM/EPM } \\
\text { CPM } \\
\text { CPM } \\
\text { CPM } \\
\text { CPM/EPM } \\
\text { CPM/EPM } \\
\text { CPM/EPM } \\
\text { CPM/EPM } \\
\text { CPM/EPM } \\
\text { EPM } \\
\text { DM }\end{array}$ \\
\hline
\end{tabular}

rapidly corrected to normal or supranormal levels. ${ }^{234950}$ It is not clear whether the low sodium or the rate of correction of the sodium is instrumental in creating the tissue damage. It has been noted that hyponatraemia has long been recognised as a common electrolyte disturbance, but CPM was not noticed before 1959. As diuretic treatment of hypertension is a common predisposing factor for CPM, the occurrence of the condition in the past three decades has been correlated with the advent of potent thiazides and with the treatment of hyponatraemia with intravenous fluids. ${ }^{39} 51$

Extrapontine myelinolysis (EPM) occurs in the same clinical setting but is seen infre- quently. ${ }^{4252}$ The first case was described by Mathieson and Olszewski in $1960,{ }^{53}$ with pathological changes seen in the cerebellum and putamen in addition to the central pons. Since that time, symmetrical demyelinating lesions are recognised to occur, in addition, in the thalamus, corpus callosum, subcortical white matter, claustrum, caudate, hypothalamus, lateral geniculate bodies, amygdala, subthalamic nuclei, substantia nigra, and medial lemnisci. ${ }^{33} 38425254$ EPM is thought to coexist with CPM in $10 \%$ of all cases, ${ }^{42} 46$ but can also occur in the absence of a pontine lesion. ${ }^{35} 55$

The aetiology of the thalamic and nigral petechial haemorrhages in our patient 3 is 
uncertain. Histological abnormalities in capillaries have been described in CPM, and CPM tends to be worse perivascularly. ${ }^{56}$ Perhaps the petechiae were related to the patient's persistent thrombocytopenia in conjunction with the ongoing myelinolysis.

CPM has occurred in patients ranging in age from 3 to 77 years, and there appears to be no gender predilection; ${ }^{43}$ of 67 patients reported since 1983, 34 are women and 33 are men. The incidence of the condition has been reported to range from $0.28 \%$ to $9.8 \%$ in necropsy series..$^{57-59}$

\section{CLINICAL PRESENTATION OF PATIENTS}

The conditions of patients with CPM/EPM range from asymptomatic to coma or a "locked-in syndrome", ${ }^{3639}$ probably depending on the extent of the areas affected by the demyelination. Common findings include behavioural abnormalities, pseudobulbar palsies, tetraplegia, hyperreflexia, ophthalmoparesis, seizures, and coma. ${ }^{31} 364660$ Frequent underlying systemic conditions include alcoholism, dehydration due to vomiting or diarrhoea, malnutrition, and burns. ${ }^{36} 58$ The condition has also been described with an increased frequency in patients undergoing orthotopic liver transplantation. ${ }^{61}$

\section{ANIMAL MODELS OF CPM/EPM}

Although occasional patients with CPM/EPM have had normal serum sodium levels or have been hypernatraemic, the majority of the earliest described patients were hyponatraemic at some point in the course of their illness. ${ }^{3744}$ This finding spawned research into experimental hyponatraemia and the production of CPM/EPM in animal models. Hyponatraemic rats, ${ }^{45}$ rabbits, ${ }^{47}$ and dogs ${ }^{46}$ treated rapidly with hypertonic saline developed CPM or EPM or both, whereas animals without treatment for their hyponatraemia developed no neuropathological changes. This caused more attention to be devoted to the rate of correction of hyponatraemia in humans rather than the hyponatraemia itself.

\section{RECOMMENDATIONS FOR TREATING \\ HYPONATRAEMIA}

Substantial disparity of opinion exists regarding the treatment of hyponatraemia. One consideration frequently used to guide therapy is the presence of symptoms, as mortality is minimal in asymptomatic patients. ${ }^{4148}$ Many authors agree with Arieff, a prominent researcher in the field of hyponatraemia, ${ }^{48}$ who advises treating symptomatic patients, but recommendations for "rates" of treatment vary widely. Arbitrarily, slow correction has been defined as changing the serum sodium by less than $0.7 \mathrm{mmol} / \mathrm{hour}$ and rapid correction as exceeding $2 \mathrm{mmol} / \mathrm{hour}^{1}$ Increasing the serum sodium by $2 \mathrm{mmol} /$ hour is advised by many studies, ${ }^{14162}$ though other authors prefer the slower rate of 0.5 $\mathrm{mmol} /$ hour. $^{3463}$ Arieff, however, has noted that the rate of correction is probably not as important as the absolute change in serum sodium, ${ }^{48}$ and suggests not increasing the serum sodium by more than $25 \mathrm{mmol}$ over the first 24 hours. A general consensus is that the patient should not be made hypernatraemic. ${ }^{1264}$

The agents used to treat the hyponatraemia have also been subjected to scrutiny: rapid correction of hyponatraemia is usually accomplished by the use of hypertonic saline, though CPM/EPM has also occurred in patients treated with isotonic saline. ${ }^{1011161719222832}$ Frusemide used in conjunction with intravenous fluids may diminish the incidence of CPM/EPM. ${ }^{465}$

Analysis of the treatments reported in table 1 in patients who ultimately developed CPM or EPM would suggest that the concentration of sodium chloride and the rate of administration make no difference to the rate of development of CPM or EPM.

\section{ANALYSIS OF PRESENT CASES}

The three patients described here presented with very low serum sodium levels and were treated differently, yet all suffered from increasing obtundation leading to coma. None of the patients were malnourished, nor was there a history of significant alcohol intake. Two patients developed EPM and cortical neuronal death while the third patient had both pontine and extrapontine myelinolysis. Cortical neuronal death mimicking the changes seen in anoxia is uncommon in extrapontine myelinolysis but has been reported in several cases. ${ }^{5253}$

These three cases emphasise the dilemma facing clinicians concerning treatment of hyponatraemia. Of the three patients presented, one was treated over the course of three days with isotonic saline, hyponatraemia in the second patient was rapidly corrected with hypertonic saline, and serum sodium in the third patient was rapidly overcorrected with hypertonic saline.

An analysis of 185 patients with symptomatic hyponatraemia reported since 1954 was undertaken. The initial serum sodium ranged from $95 \mathrm{mmol} / 1$ to $124 \mathrm{mmol} / \mathrm{l}$ and symptoms varied from weakness and lethargy to seizures and frank coma. Fifty three patients treated with hypertonic saline improved and the clinical condition of 43 worsened. Eighteen patients treated with normal saline improved and nine worsened. Twenty seven patients were treated only with water restriction: all were felt to have improved. Thirty five patients were treated only by the withdrawal of diuretics and all improved. It should be noted that these numbers do not reflect the thousands of hyponatraemic patients, treated in various fashions, with both favourable and poor outcomes, all of whom are unreported.

The absolute change in serum sodium, suggested to be the inciting factor of myelinolysis by Arieff, ${ }^{48}$ in our three patients was 9 $\mathrm{mmol} / 24$ hours, $23 \mathrm{mmol} / 8$ hours, and 41 $\mathrm{mmol} / 24$ hours. In the 67 reported cases of CPM since 1983, information concerning absolute change of serum sodium was available in 51 patients. Twenty patients had an increase in serum sodium of less than 15 
mmol/24 hours, although the hyponatraemia in five of the patients was overcorrected. The increase in 12 patients ranged from 16 to 25 $\mathrm{mmol} / 24$ hours, with three overcorrections. Seventeen patients sustained an increase in serum sodium ranging from 26 to 40 $\mathrm{mmol} / 24$ hours (with one overcorrection). Successive sodium levels 24 hours apart were more than $40 \mathrm{mmol}$ greater in two additional patients. Although these numbers are too small to prove or disprove a theory, correction of the hyponatraemia in 34 of these patients (including two of the current cases) fall into the recommended $25 \mathrm{mmol} / 24$ hour increase in serum sodium, ${ }^{48}$ yet the patients still suffered from myelinolysis.

Our three cases of CPM/EPM, combined with a review of reported cases since 1983, seem to suggest that none of these factors (the rate of serum sodium correction, the absolute sodium change, or the solution employed) are the critical factors in the prevention of central or extrapontine myelinolysis. There have been no patients with hyponatraemia documented to have CPM or EPM either by radiological studies or autopsy who have been treated with water restriction only, and allowed to "self-correct" their hyponatraemia. This review would suggest that water restriction combined with cessation of diuretic therapy and observation may lead to a more salutary outcome, and may be reasonable in some patients with symptomatic hyponatraemia and normal renal function. Further research based on animal models might identify an additional factor in the treatment of hyponatraemia which will enable clinicians to prevent this frequently fatal condition.

We thank Mr Don Morse for photographic assistance.

1 Ayus JC, Krothapalli RK, Arieff AI. Changing concepts in treatment of severe symptomatic hyponatremia. $\mathrm{Am} \mathrm{f}$ Med 1985;78:897-902.

2 Ayus JC, Krothapalli RK, Arieff AI. Treatment of symptomatic hyponatremia and its relation to brain damage. $N$ Engl f Med 1987;317:1190-5.

3 Sterns RH, Riggs JE, Schochet SS. Osmotic demyelination syndrome following correction of hyponatremia. $N$ Engl f Med 1986;314:1535-42.

4 Cluitmans FHM, Meinders AE. Management of severe hyponatremia: rapid or slow correction? $A m \mathcal{F} \mathrm{Med}$ 1990;88:161-6.

5 Hazratji SMA, Kim RC, Lee SH, et al. Evolution of pontine and extrapontine myelinolysis. $\mathcal{f}$ Comput Assist Tomogr 1983;7:356-61.

6 Kalnins RM, Berkovic SF, Bladin PF. Central pontine myelinolysis with widespread extrapontine lesions: myelinolysis with widespread extrapontine lesions:

7 Stam J, van Oers MHJ, Verbeeten B. Recovery after central pontine myelinolysis. $\mathcal{f}$ Neurol $1984 ; 231: 52-3$.

8 Brunner JE. Central pontine myelinolysis in a patient with adrenal insufficiency. Henry Ford Hosp Med $\mathscr{f}$ 1985;33:45-7.

9 Kold $\AA$, Johansen O, Reintoft I, et al. Central pontine myelinolysis - a case report with typical neuropathological findings. Acta Neurol Scand 1986;73:260-3.

10 De Cunha C, Bertotini TE, Lawrence J, et al. Central pontine myelinolysis-a preventable condition. I Tenn Med Assoc 1986;79:469-72.

11 Nielsen JM. Central pontine myelinolysis complicating hyponatremia. Med $\mathcal{f}$ Aust 1987;146:492-4.

12 Peces R, Ablanedo P, Alvarez J. Central pontine and extrapontine myelinolysis following correction of severe hyponatremia. Nephron 1988;49:160-3.

13 Walker JV, Englander RN. Central pontine myelinolysis following rapid correction of hyponatremia in an alcoholic. Am 7 Kidney Dis 1988;12:531-3.

14 Weissman JD, Weissman BM. Pontine myelinolysis and delayed encephalopathy following the rapid correction of acute hyponatremia. Arch Neurol 1989;46:926-7.

15 Estol CJ, Faris AA, Martinez AJ, et al. Central pontine myelinolysis after liver transplantation. Neurology 1989;39:493-8.

16 Oh MS, Uribarri J, Barrido D, et al. Case report: danger of central pontine myelinolysis in hypotonic dehydration and recommendation for treatment. $\mathrm{Am} F \mathrm{Med} S \mathrm{Si}$ 1989;298:41-3.

17 Castillo RA, Ray RA, Yaghmai F. Central pontine myelinolysis and pregnancy. Obstet Gynecol 1989;3:459-61.

18 Clifford DB, Gado MH, Levy BK. Osmotic demyelination syndrome-lack of pathologic and radiologic imaging correlation. Arch Neurol 1989;46:343-7.

19 Marra TR. Hemiparesis apparently due to central pontine myelinolysis following hyponatremia. Ann Neurol 1983;14:687-8.

20 Kandt RS, Heldrich FJ, Moser HW. Recovery from probable central pontine myelinolysis associated with able central pontine myelinolysis associa
Addison's disease. Arch Neurol 1983;40:1 18-9.

21 Gerber O, Geller M, Stiller J, et al. Central pontine myelinolysis-resolution shown by computed tomography. Arch Neurol 1983;40:116-8.

22 Price DB, Kramer J, Hotman GC, et al. Central pontine myelinolysis: report of a case with distinctive appearance on MR imaging. A7NR 1987;8:576-7.

23 Rosenbloom S, Buchholz D, Kumar AJ, et al. Evolution of central pontine myelinolysis on CT. AfNR 1984;5:110-2.

24 DeWitt LD, Buonanno FS, Kistler JP, et al. Central pontine myelinolysis: demonstration by nuclear magnetic tine myelinolysis: demonstration by

25 Takeda K, Sakuta M, Saeki F. Central pontine myelinolysis diagnosed by magnetic resonance imaging. Ann Neurol 1985;17:310-1.

26 Steinsapir KD, Vinters HV. Central pontine myelinolysis in a child with the Shwachman-Diamond syndrome. Hum Pathol 1985;16:741-3.

27 Thompson PD, Gledhill RF, Quinn NP, et al. Neurological complications associated with parenteral treatment: central pontine myelinolysis and Wernicke's encephalopathy. $B M F$ 1986;292:684-5.

28 Rodriguez ML, Hankey GJ. The "locked-in syndrome" and alcoholism - a preventable complication. Med $f$ Aust 1987;146:487-92

29 Redmond J, Brunner J, Haggar A, et al. Central pontine myelinolysis: evolution following correction of acute hyponatremia shown by MRI (abstract). Neurology hyponatremia shown

30 Grafton ST, Bahls F, Bell KR. Acquired dystonia following central pontine myelinolysis (abstract). Neurology 1987;37(suppl):276.

31 Price BH, Mesulam MM. Behavioral manifestations of central pontine myelinolysis. Arch Neurol 1987;44:671-3.

32 Rippe DJ, Edwards MK, D'Amour PG, et al. MR imaging of central pontine myelinolysis. F Comput Assist Tomogr 1987;11:724-6.

33 Boon AP, Potter AE. Extensive extrapontine and central pontine myelinolysis associated with correction of profound hyponatremia. Neuropathol Appl Neurobiol 1987;13:1-9.

34 Zegers de Beyl D, Flament-Durand J, Borenstein S, et al. Ocular bobbing and myoclonus in central pontine myelinolysis. f Neurol Neurosurg Psychiatry myelinolysis.

35 Okeda R, Kitano M, Sawabe $M$, et al. Distribution of demyelinating lesions in pontine and extrapontine myelinolysis - three autopsy cases including one case devoid of central pontine myelinolysis. Acta Neuropathol 1986;69:259-66.

36 Adams RD, Victor M, Mancall EL. Central pontine myelinolysis-a hitherto undescribed disease occurring in alcoholic and malnourished patients. Arch Neurol Psychiat 1959;81:154-72.

37 Conger JD, McIntyre JA, Jacoby WJ. Central pontine myelinolysis associated with inappropriate antidiuretic hormone secretion. Am $\mathcal{f} \mathrm{Med}$ 1969;47:813-7.

38 Finlayson MH, Snider S, Oliva LA, et al. Cerebral and pontine myelinolysis--two cases with fluid and elecpontine myelinolysis-two cases with fluid and electrolyte imbalance

39 Messert B, Orrison WW, Hawkins MJ, et al. Central pontine myelinolysis-considerations on etiology, diagnosis and treatment. Neurology 1979;29:147-60.

40 Telfer RB, Miller EM. Central pontine myelinolysis following hyponatremia, demonstrated by computerized tomography. Ann Neurol 1979;6:455-6.

41 Arieff AI. Hyponatremia, convulsions, respiratory arrest and permanent brain damage after elective surgery in healthy women. $N$ Engl f Med 1986;314:1529-35.

42 Tomlinson BE, Pierides AM, Bradley WG. Central pontine myelinolysis-two cases with associated electrolyte tine myelinolysis- - two cases with associa

43 Monseu G, Flament-Durand J. Pathogenesis of central pontine myelinolysis. A clinical and pathological pontine myelinolysis. A clinical and pathological
description of three cases. Path Europ 1971;6 1:75-94.

44 Burcar PJ, Norenberg MD, Yarnell PR. Hyponatremia and central pontine myelinolysis. Neurology $1977 ; 27: 223-6$

45 Kleinschmidt-DeMasters BK, Norenberg MD. Rapid correction of hyponatremia causes demyelination: relation to central pontine myelinolysis. Science 1981;211: 1068-70.

46 Laureno $R$. Central pontine myelinolysis following rapid correction of hyponatremia. Ann Neurol 1983;13: $232-42$.

47 Illowsky BP, Laureno R. Encephalopathy and myelinolysis 
after rapid correction of hyponatremia. Brain 1987;110 855-67.

48 Arieff AI. Hyponatremia (Grand Rounds). Mt Sinai $f$ Med 1990;57:125-35.

49 Leslie KO, Robertson AS, Norenberg MD. Central pontine myelinolysis: an osmotic gradient pathogenesis

50 Norenberg MD, Leslie KO, Robertson AS. Association between rise in serum sodium and central pontine myelinolysis. Ann Neurol 1982;11:128-35.

51 Aleu FP, Terry RD. Central pontine myelinolysis. Arch Pathol 1963;76:140-6.

52 Wright DG, Laureno R, Victor M. Pontine and extrapontine myelinolysis. Brain 1979;102:361-85.

53 Mathieson G, Olszewski J. Central pontine myelinolysis with other cerebral changes. Neurology 1960;10:345-54.

54 Monteiro L. La myélinolyse du centre du pont dans le cadre d'un nouveau syndrome histopathologique de cadre d'un nouveau syndrome histopathologique de topograp

55 Laureno R, Karp BI. Pontine and extrapontine myelinolysis following rapid correction of hyponatremia. Lancet 1988;i:1439-41.

56 Norenberg MD. A hypothesis of osmotic endothelial injury-a pathogenetic mechanism in central pontine myelinolysis. Arch Neurol 1983;40:66-9.

57 Endo Y, Oda M, Hara M. Central pontine myelinolysis- a study of 37 cases in 1000 consecutive autopsies. Acta Neuropathol 1981;53:145-53.

58 McKee AC, Winkelman MD, Banker BQ. Central pontine myelinolysis in severely burned patients: relationship to serum hyperosmolality. Neurology 1988;38

59 Gocht A, Colmant HJ. Central pontine and extrapontine myelinolysis: a report of 58 cases. Clin Neuropathol 1987;6:262-70

60 McCormick SF, Danneel CM. Central pontine myelinolysis. Arch Intern Med 1967;119:444-78.

61 Starzl TE, Schneck SA, Mazzoni G, et al. Acute neurological complications after liver transplantation with particular reference to intraoperative cerebral air embolus. Ann Surg 1978;187:236-40.

62 Narins RG. Therapy of hyponatremia-does haste make waste? N Engl f Med 1986;314:1573-5.

63 Valenstein E, Watson RT, Quisling RG. Neostriatal lesions in the osmotic demyelination (abstract).

64 Ayus JC, Krothapalli RK, Arieff AI, et al. Overcorrection rather than rapid correction induces central pontine myelinolysis in patients with severe hyponatremia (abstract). Kidney Int 1985;27:132.

65 Worthley LIG, Thomas PD. Treatment of hyponatremic seizures with intravenous $29 \cdot 2 \%$ saline. $B M^{\mathcal{F}}$ 1986;292:168-70. 